\title{
Nasal Cavity and Ethmoid Sinus Cancer pT3 TNM Finding v8
}

National Cancer Institute

\section{Source}

National Cancer Institute. Nasal Cavity and Ethmoid Sinus CancerpT3 TNM Finding v8. NCI Thesaurus. Code C133045.

Nasal cavity and ethmoid sinus cancer with tumor invading the medial wall or floor of the orbit, maxillary sinus, palate, or cribriform plate. (from AJCC 8th Ed.) 